\title{
Financial aspects of transport infrastructure development in regions
}

\author{
Vyacheslav Bubnov, ${ }^{1, *}$, and Yulia Bubnova ${ }^{2}$ \\ ${ }^{1}$ Irkutsk State University of Railway Engineering, 664074 Irkutsk, Russia \\ ${ }^{2}$ Baikal State University, 664003 Irkutsk, Russia
}

\begin{abstract}
The level of economic development depends on many factors, among which infrastructure, including railway transport, is the key one. Financing of infrastructure-related projects on the regional level encourages economic growth. However, different level of overall development of subject of the Russian Federation causes inequality in the level of transport infrastructure development and makes common approach to its financing inapplicable. The necessity appears to build a model of financing for transport-related infrastructure with the use of statistical data and mathematical approach with the account of regional market peculiarities. Due to selection of indicators affecting economic growth and building parametric factor model, classification of financing on subfederal level was carried out, which makes it applicable for states with federal structure.
\end{abstract}

\section{Introduction}

Current state of world economy reveals rather serious disproportions in economic development of certain regions. Usually, the main part of financial resources is concentrated in financial centers where the key infrastructure-related investment projects are implemented. Divergent development of big territorial entities occurs [1], which causes subsequent flow of labor, material, intellectual and other resources from the periphery to the center. It results in slowdown of growth rate in both leading global economies and developing countries.

The problems of economic growth in developing countries are vastly studied. The works of A. Elekes and P. Halmai [2] revealed that the model of economic growth and convergence effective up to 2008, is inapplicable for current conditions in these countries. Study of the Bank for International Settlements demonstrated why too rapid growth of financial sector has negative effect on the overall economy [3]. Particularly, the resource supply of economic growth leads to the deficit of public finances. According to D. Mauldin and D. Tepper [4], if one fails to get control of the USA budget deficit, it will reach $200 \%$ of the GDP by 2025, which will bring the leading global financial system in an unstable position. The main factor of financial capital allocation in such conditions is not the reliability of capital maintenance, but the proximity to functioning markets [5]. According

\footnotetext{
*Corresponding author: bubnovva13@gmail.com
} 
to Ph. Hugon [6], this leads the global economy to asymmetry and contradictions between periphery and center.

As a result, the role of corporate finances in economic growth is enhanced, to meet the needs of such capitals offshore companies are formed. The initial purpose of creating tax shelters to enable transnational corporations to enter new markets [7] transformed into "black holes in the global economy" [8], which has a detrimental effect on public finances disturbing their sovereignty [9]. Deep contradictions are formed between public and corporate finances.

Some authors believe in the ability to unite financial systems [10], others prove negative effect on the economic development caused by incompatible national finances [11-13]. According to W. Van Lear and J. Sisk [14], major corporations switched from performance strategy mainly based on the national economy framework to the strategy of direct foreign investments, which according to M. Woodford [15] requires unconventional measures.

Active and rational participation of the government in financing is necessary to overcome these negative tendencies [16]. Development and growth of national economy is only possible when based on subfederal level development.

\section{Research methods}

When studying subfederal level, a reasonable suggestion shall be made, that regions have different levels of development, which makes common approach to financing of economic development inapplicable. Consequently, it is important to classify regions on the basis of factors affecting economic growth and development from the viewpoint of financing.

A parametric model is used to build a factor model of financing, it enables to interpret the results obtained in research and practical activities. Per capita gross regional product (internal factor $-\mathrm{y}$ ) was taken as a target parameter, which depends on external variables $\mathrm{x}_{1}, \mathrm{x}_{2}, \ldots, \mathrm{x}_{\mathrm{m}}$, given in Table 1 . In order to provide comparability of the economic growth parameter on the subfederal level it was recalculated as per capita gross regional product for a certain region and chosen time period (Table 1). The given calculations showed that in various regions economic growth is affected by different factors, which became the basis for classification [17].

Table 1. Classification of financing in regions with regard to the effect on economic growth.

\begin{tabular}{|c|c|}
\hline Region type & Factor affecting economic growth \\
\hline $\begin{array}{l}\text { Quasi- } \\
\text { corporation } \\
\text { region }\end{array}$ & $\begin{array}{l}\mathrm{x}_{3}-\text { investments in fixed capital per capita } \\
\mathrm{x}_{4}-\text { capital/labor ratio in all organizations } \\
\mathrm{x}_{5}-\text { organizational demography } \\
\mathrm{x}_{6}-\text { railway transportation of cargo }\end{array}$ \\
\hline $\begin{array}{l}\text { Quasi-state } \\
\text { region }\end{array}$ & $\begin{array}{l}\mathrm{x}_{1}-\text { per capita expenses of consolidated regional budget } \\
\mathrm{x}_{2}-\text { per capita expenses of state non-budgetary funds } \\
\mathrm{x}_{10}-\text { per capita share of public employees }\end{array}$ \\
\hline Society region & $\begin{array}{l}\mathrm{x}_{7}-\text { annual per capita income } \\
\mathrm{x}_{8}-\text { annual level of occupation } \\
\mathrm{x}_{9}-\text { level of citizens' economic activity }\end{array}$ \\
\hline
\end{tabular}

Official data on subjects of the Russian Federation and federal districts for the period 2000-2014 were taken as a statistical basis for calculations. Software products were used when solving computational problems, and the best model was selected based on multicriteria approach (Table 2), which allowed defining factors financing of which affect economic growth. Additionally, factors having negative effect on economic growth were 
defined. The obtained results became the basis for shaping state finance policy in the conditions of limited financial resources of the Russian society.

Table 2. Federal districts of the Russian Federation factor model of financing economic growth in 2000-2014 [17].

\begin{tabular}{|l|l|}
\hline \multicolumn{1}{|c|}{ Federal district } & \multicolumn{1}{c|}{ Model } \\
\hline Central & $\mathrm{y}=-1.05 \mathrm{e}^{5}+3.49 \mathrm{x}_{2}+5.61 \mathrm{x}_{3}-42.9 \mathrm{x}_{4}-0.321 \mathrm{x}_{7}+1.74 \mathrm{e}^{5} \mathrm{x}_{10}$ \\
\hline Northwest & $\mathrm{y}=-1.10 \mathrm{e}^{05}+2.46 \mathrm{x}_{1}+129 \mathrm{x}_{4}+709 \mathrm{x}_{6}$ \\
\hline South & $\mathrm{y}=-2.37 \mathrm{e}^{4}+5.72 \mathrm{x}_{1}-55.9 \mathrm{x}_{4}+598 \mathrm{x}_{6}$ \\
\hline North Caucasus & $\mathrm{y}=-1.40 \mathrm{e}^{4}+1.04 \mathrm{x}_{1}+2.14 \mathrm{x}_{2}+1.30 \mathrm{e}^{3} \mathrm{x}_{6}$ \\
\hline Volga & $\begin{array}{l}\mathrm{y}=-359895-3.858 \mathrm{x}_{1}+3.132 \mathrm{x}_{3}+177.46 \mathrm{x}_{4}+156.33 \mathrm{x}_{6}+180.64 \mathrm{x}_{8} \\
+4899.94 \mathrm{x}_{9}\end{array}$ \\
\hline Ural & $\mathrm{y}=-3.43 \mathrm{e}^{5}+1.80 \mathrm{x}_{1}+4.81 \mathrm{x}_{2}+1.35 \mathrm{e}^{03} \mathrm{x}_{6}+2.68 \mathrm{e}^{5} \mathrm{x}_{10}$ \\
\hline Siberia & $\mathrm{y}=-1.03 \mathrm{e}^{5}+2.40 \mathrm{x}_{2}+1.21 \mathrm{x}_{3}+258 \mathrm{x}_{6}+4.56 \mathrm{e}^{4} \mathrm{x}_{10}$ \\
\hline Far East & $\mathrm{y}=-2.56 \mathrm{e}^{4}+3.45 \mathrm{x}_{2}+0.786 \mathrm{x}_{3}+32.7 \mathrm{x}_{4}+0.0567 \mathrm{x}_{7}+3.45 \mathrm{e}^{04} \mathrm{x}_{10}$ \\
\hline
\end{tabular}

\section{Experimental data and results}

Classification of economic growth financing was performed with regard to subjects of the Russian Federation, it includes: quasi-corporation regions - 44; quasi-state regions - 23; society-regions - 13; non-defined - 2 [17], which enables to make the following conclusions:

- subjects of the Russian Federation significantly differ in their level of development;

- comparability of factors affecting economic growth and development are nonexistent, even with regard to federal districts;

- the selected factors have both positive and negative effect on economic growth (Table 3), which proves inability to apply a common approach to financing;

- the existing division into federal districts is carried out formally and is based on geographical characteristics, which hampers growth of financing efficiency.

Financing of economic growth shall be performed on the basis of the suggested classification of financing of subjects of the Russian Federation.

Table 3. Synthesis of factors affecting economic growth on subfederal level (without the account of federal districts) [18].

\begin{tabular}{|l|c|c|c|c|c|c|c|c|c|c|c|}
\hline \multicolumn{1}{|c|}{ Indicator } & $\mathbf{x}_{\mathbf{1}}$ & $\mathbf{x}_{\mathbf{2}}$ & $\mathbf{x}_{\mathbf{3}}$ & $\mathbf{x}_{\mathbf{4}}$ & $\mathbf{x}_{\mathbf{5}}$ & $\mathbf{x}_{\mathbf{6}}$ & $\mathbf{x}_{\mathbf{7}}$ & $\mathbf{x}_{\mathbf{8}}$ & $\mathbf{x}_{\mathbf{9}}$ & $\mathbf{x}_{\mathbf{1 0}}$ & Total \\
\hline $\begin{array}{l}\text { Number of factors with } \\
\text { positive effect }\end{array}$ & 21 & 24 & 26 & 19 & 0 & 17 & 29 & 15 & 7 & 11 & 169 \\
\hline $\begin{array}{l}\text { Number of factors with } \\
\text { negative effect }\end{array}$ & 9 & 12 & 18 & 15 & 0 & 17 & 16 & 6 & 18 & 19 & 130 \\
\hline Total number of factors & 30 & 36 & 44 & 34 & 0 & 34 & 45 & 21 & 25 & 30 & 299 \\
\hline \% of positive effect & 26.3 & 30.0 & 32.5 & 23.8 & 0.0 & 21.3 & 36.3 & 18.8 & 8.8 & 13.8 & 21.1 \\
\hline \% of negative effect & 11.3 & 15.0 & 22.5 & 18.8 & 0.0 & 21.3 & 20.0 & 7.5 & 22.5 & 23.8 & 16.3 \\
\hline
\end{tabular}

When financing on the subfederal level, the following peculiarities found while model testing shall be accounted (Table 4):

- increase in financing of small and medium-sized enterprises is only reasonable for the purpose of social development, since organizational demography factor has no effect on economic growth in any of the regions; 
- railway transportation of cargo can have both positive and negative effect on economic growth depending on the region, therefore, financing of railway transport development may affect the uncontrolled finance reallocation on the subfederal level;

- shadow market and tax evasion by self-employed civilians (factor of level of citizens' economic activity) effect economic growth negatively;

- reformation of finance allocation on payments for government employees is necessary when reaching a quasi-state level, since in this case the share of government employees is a negative factor.

The performed analysis showed that subjects of Siberian federal district belong to quasicorporations (8 subjects) and quasi-states (4 subjects), which makes common policy of reasonable financing applicable. Let us consider factor model of economic growth financing in more detail (Table 4).

Table 4. Factor model of financing economic growth in subjects of the Russian Federation included in Siberian federal district, for 2000-2014 [17].

\begin{tabular}{|l|l|l|}
\hline \multicolumn{1}{|c|}{ Region } & \multicolumn{1}{|c|}{ Model } & $\begin{array}{l}\text { Determina } \\
\text { tion } \\
\text { criterion }\end{array}$ \\
\hline Altai Republic & $\mathrm{y}=-2.12 \mathrm{e}^{4}+19.7 \mathrm{x}_{4}+9.33 \mathrm{e}^{5} \mathrm{x}_{10}$ & $\mathrm{R}^{2}=0.275$ \\
\hline Republic of Buryatia & $\mathrm{y}=-1.01 \mathrm{e}^{5}+4.17 \mathrm{x}_{2}+1.66 \mathrm{e}^{3} \mathrm{x}_{6}-0.0552 \mathrm{x}_{7}+6.13 \mathrm{e}^{6} \mathrm{x}_{10}$ & $\mathrm{R}^{2}=0.909$ \\
\hline Tyva Republic & $\begin{array}{l}\mathrm{y}=-5143.46-0.484 \mathrm{x}_{1}+0.186 \mathrm{x}_{3}+0.21 \mathrm{x}_{7}+ \\
+486.83 \mathrm{x}_{8}-253.34 \mathrm{x}_{9}-124015 \mathrm{x}_{10}\end{array}$ & $\mathrm{R}^{2}=0.987$ \\
\hline Republic of Khakassia & $\mathrm{y}=-3.33 \mathrm{e}^{4}+0.720 \mathrm{x}_{3}+0.636 \mathrm{x}_{7}$ & $\mathrm{R}^{2}=0.957$ \\
\hline Altai Krai & $\mathrm{y}=-1.04 \mathrm{e}^{6}+684 \mathrm{x}_{4}-0.163 \mathrm{x}_{7}+7.69 \mathrm{e}^{3} \mathrm{x}_{8}+6.35 \mathrm{e}^{3} \mathrm{x}_{9}$ & $\mathrm{R}^{2}=0.958$ \\
\hline Zabaykalsky Krai & $\mathrm{y}=-9.83 \mathrm{e}^{4}+25.6 \mathrm{x}_{1}-2.26 \mathrm{x}_{2}-16.7 \mathrm{x}_{3}$ & $\mathrm{R}^{2}=0.720$ \\
\hline Krasnoyarsk Krai & $\mathrm{y}=4.56 \mathrm{e}^{5}+222 \mathrm{x}_{2}-63.4 \mathrm{x}_{3}-1.07 \mathrm{e}^{4} \mathrm{x}_{4}+45.7 \mathrm{x}_{7}$ & $\mathrm{R}^{2}=0.925$ \\
\hline Irkutsk region & $\mathrm{y}=-72031.3+3.58133 \mathrm{x}_{2}+0.28136 \mathrm{x}_{7}+$ & $\mathrm{R}^{2}=0.999$ \\
\hline Kemerovo region & $\mathrm{y}=-2.43 \mathrm{e}^{5}+25.7 \mathrm{x}_{1}-3.31 \mathrm{x}_{2}$ & $\mathrm{R}^{2}=0.705$ \\
\hline Novosibirsk region & $\mathrm{y}=-1.28 \mathrm{e}^{5}+14.5 \mathrm{x}_{3}+5.71 \mathrm{e}^{3} \mathrm{x}_{6}-0.403 \mathrm{x}_{7}$ & $\mathrm{R}^{2}=0.946$ \\
\hline Omsk region & $\begin{array}{l}y=3733780-36,45 x_{1}+12,23 x_{3}+2472,36 x_{4}- \\
-64598,8 x_{6}-2,28 x_{7}-23586,8 x_{9}-110316000 x_{10}\end{array}$ & $\mathrm{R}^{2}=1$ \\
\hline Tomsk region & $\mathrm{y}=1.75 \mathrm{e}^{5}-4.15 \mathrm{x}_{3}+5.85 \mathrm{e}^{4} \mathrm{x}_{6}+5.47 \mathrm{x}_{7}-5.37 \mathrm{e}^{7} \mathrm{x}_{10}$ & $\mathrm{R}^{2}=0.966$ \\
\hline
\end{tabular}

Having analyzed the data in Table 4, a valid conclusion can be made that there are no regions with identical models in Siberian federal district. Besides, Altai Republic and Kemerovo region have low determination criteria and require in-depth study.

Reasonable financing can be focused on both enhancing factors with positive effect on economic growth and minimizing those with negative effect. Below is suggested the conceptual approach applied to subjects of Siberian federal district (Table 5). 
Table 5. Conceptual approaches to reasonable financing [17].

\begin{tabular}{|c|c|c|}
\hline $\begin{array}{c}\text { Type of } \\
\text { subject of } \\
\text { the Russian } \\
\text { Federation }\end{array}$ & $\begin{array}{l}\text { Subject of the } \\
\text { Russian } \\
\text { Federation }\end{array}$ & Conceptual approaches to reasonable financing \\
\hline \multirow{8}{*}{$\begin{array}{l}\text { Quasi- } \\
\text { corporation }\end{array}$} & Altai Republic & $\begin{array}{l}\text { Corporate tax exemptions, development of loyal business } \\
\text { environment }\end{array}$ \\
\hline & $\begin{array}{l}\text { Republic of } \\
\text { Buryatia }\end{array}$ & Financing of social sphere, corporate tax exemptions \\
\hline & Tyva Republic & $\begin{array}{l}\text { Public-private projects, corporate tax exemptions, financing of } \\
\text { creating jobs, rationalized approach to regional budget } \\
\text { allocation }\end{array}$ \\
\hline & $\begin{array}{l}\text { Republic of } \\
\text { Khakassia }\end{array}$ & Corporate tax exemptions, financing of creating jobs \\
\hline & Altai Krai & $\begin{array}{l}\text { Corporate tax exemptions, financing of creating jobs, financing } \\
\text { of social sphere }\end{array}$ \\
\hline & $\begin{array}{l}\text { Novosibirsk } \\
\text { region }\end{array}$ & Corporate tax exemptions, financing of social sphere \\
\hline & $\begin{array}{l}\text { Omsk } \\
\text { region }\end{array}$ & $\begin{array}{l}\text { Corporate tax exemptions, rationalized approach to regional } \\
\text { budget allocation, financing of social sphere }\end{array}$ \\
\hline & $\begin{array}{l}\text { Tomsk } \\
\text { region }\end{array}$ & $\begin{array}{l}\text { Corporate tax exemptions, development of loyal business } \\
\text { environment }\end{array}$ \\
\hline \multirow{4}{*}{ Quasi-state } & $\begin{array}{l}\text { Zabaykalsky } \\
\text { Krai }\end{array}$ & $\begin{array}{l}\text { Creation of comfortable business environment and social } \\
\text { infrastructure, increase of federal budget subsidies }\end{array}$ \\
\hline & $\begin{array}{l}\text { Krasnoyarsk } \\
\text { Krai }\end{array}$ & $\begin{array}{l}\text { Financing of social sphere by increasing costs of state non- } \\
\text { budgetary foundations, financing of creating jobs, creation of } \\
\text { comfortable business environment }\end{array}$ \\
\hline & Irkutsk region & $\begin{array}{l}\text { Financing of social sphere by increasing costs of state non- } \\
\text { budgetary foundations, financing of creating jobs, financing } \\
\text { law enforcement authorities working against shadow market }\end{array}$ \\
\hline & $\begin{array}{l}\text { Kemerovo } \\
\text { region }\end{array}$ & $\begin{array}{l}\text { Increase of federal budget subsidies and grants, financing of } \\
\text { social sphere }\end{array}$ \\
\hline
\end{tabular}

Rational financing is impossible without attracting corporate finances of railway transport industry. The key member of this industry is Russian Railways JSC which has the following structure of project finance sources (Table 6).

Table 6. Structure of project finance sources in Russian Railways JSC in 2017 (\%) [19].

\begin{tabular}{|l|c|c|c|c|c|}
\hline \multicolumn{1}{|c|}{ Indicator } & $\mathbf{2 0 1 3}$ & $\mathbf{2 0 1 4}$ & $\mathbf{2 0 1 5}$ & $\mathbf{2 0 1 6}$ & $\mathbf{2 0 1 7}$ \\
\hline Amount of profit & 0.1 & -4.5 & 0.0 & 0.6 & 1.4 \\
\hline $\begin{array}{l}\text { Increase of authorized } \\
\text { capital }\end{array}$ & 12.6 & 5.4 & 10.1 & 5.0 & 5.4 \\
\hline $\begin{array}{l}\text { Financial resources of } \\
\text { budget and non- } \\
\text { budgetary foundations }\end{array}$ & 0.136 & 5.898 & 0.230 & 0.048 & 0.136 \\
\hline Finance lease & 3.4 & 5.1 & 5.5 & 6.8 & 6.9 \\
\hline Credits & 35.4 & 49.6 & 42.3 & 40.2 & 43.3 \\
\hline Bonded loans & 48.4 & 38.5 & 41.8 & 47.4 & 42.8 \\
\hline Total amount & 100 & 100 & 100 & 100 & 100 \\
\hline
\end{tabular}

The projects are financed from various sources: own resources (income and depreciation reserve), government support (also by increasing the capital of Russian Railways JSC), loaned funds (credits, bonded loans). The major part is represented by 
loaned funds (more than 90\%) including credits, bonded loans and leasing. However, these resources are obviously insufficient. It shall be noted that in 2018 capital investments in Eastern operating domain alone exceed 1.5 billion rubles [20].

Table 7. Capital investment of Russian Railways JSC in development of Eastern operation domain (million rubles, excl. VAT).

\begin{tabular}{|l|c|c|c|c|c|c|}
\hline \multicolumn{1}{|c|}{ Project title } & $\mathbf{2 0 1 3}$ & $\mathbf{2 0 1 4}$ & $\mathbf{2 0 1 5}$ & $\mathbf{2 0 1 6}$ & $\mathbf{2 0 1 7}$ & $\mathbf{2 0 1 8}$ \\
\cline { 2 - 7 } & \multicolumn{3}{|c|}{ actual } & & \multicolumn{2}{|c|}{ plan } \\
\hline $\begin{array}{l}\text { Improvement of railway } \\
\text { infrastructure of Baikal-Amur } \\
\begin{array}{l}\text { Mainline and Trans-Siberian } \\
\text { Railway with enhanced traffic } \\
\text { and freight-carrying capacity }\end{array}\end{array}$ & $4,072.8$ & $21,656.1$ & $64,208.8$ & $83,526.2$ & $70,999.4$ & $86,200.3$ \\
\hline $\begin{array}{l}\text { Complex development of the } \\
\text { Mezhdurechensk - Taishet } \\
\text { section of Krasnoyarsk railway }\end{array}$ & $1,709.0$ & $4,639.7$ & $5,949.4$ & $4,766.5$ & $3,646.4$ & $6,756.1$ \\
\hline $\begin{array}{l}\text { Improvement of Baikal-Amur } \\
\text { Mainline and Trans-Siberian } \\
\text { Railway }\end{array}$ & & & & & & 270.0 \\
\hline $\begin{array}{l}\text { Increase of traffic capacity of } \\
\text { Artysh - Mezhdurechensk - } \\
\text { Taishet section }\end{array}$ & & & & & & $1,275.4$ \\
\hline
\end{tabular}

Search of new financial instruments is a relevant task. Infrastructure mortgage may become one of public-private partnership tools. The essence of this option consists in the possibility to use part of future tax revenues from project implementation for covering mortgage payments. Capital investments of a company may be made with the government support in the form of guarantees and further payment for this infrastructure while using it. When such system is applied, a bank shall offer affordable credits to the construction companies who shall build infrastructure facilities at the lowest possible cost. Then, the government starts paying the companies for them to repay the credit using the finances of the infrastructure beneficiary, with the minimum increase in taxes and payments. In fact, such infrastructure facilities are purchased on loaned funds from private investors and the users of the facility gradually repay this loan.

\section{Conclusion}

As the result of the study the recommendations were elaborated for financing development on subfederal level. It was proved that the use of common financing model on the subfederal level is impossible. Therefore, relevant models shall be chosen depending on classification of the region financing and the funding streams with confirmation of efficiency using the described factor model; this also applies to financing of railway infrastructure projects. Due to the classification of economic growth financing, conceptual approaches to reasonable financing were formulated which shall be accounted in transport infrastructure development.

The existing division of the economy into public and private (based on recommendation of Anglo-Saxon economists) is obsolete and doesn't meet economic development interests. The sector of public interests shall be defined and include systemically important financial institutions (like Russian Railways JSC), the activity of which impact the overall country development.

To reach the development goals new financial tools should be used, including infrastructure mortgage which is a public-private partnership instrument. This will provide 
additional tax revenues and development of finance and credit sector, as well as economic growth on the regional level.

Some additional research are required before practical use of the obtained results of the study, which will concern reciprocal effect of transport infrastructure and finance and credit system on the regional level. However, the outcomes of the study define the direction for further reserach.

\section{References}

1. RosStat, Gosudarstvo, obshhestvennye organizacii [The State, public organizations], Available at:

http://www.gks.ru/wps/wcm/connect/rosstat_main/rosstat/ru/statistics/state/\# (May 14, 2018). (in Russian)

2. A. Elekes, P. Halmai, Intereconomics, Vol. 48, 2, 124-130 (2013).

3. Vesti. Ekonomika, The Economist: finansovyj bum meshaet rostu jekonomiki [The Economist: financial boom hinders economic growth], Available at: http://www.vestifinance.ru/articles/53638 (20.02.2015).

4. D. Mauldin, D. Tepper, Endgame: The End of the Debt Supercycle and How It Changes Everything (Mif, Moscow, 2013). (in Russian)

5. S. Pavoni, The Banker, 16-17 (2011).

6. Ph. Hugon, Problemes econ P., 3011, 41-48 (2011).

7. Frère Albert. Le site des gros PatriMoines, Les paradis fiscaux, source d'enfer social et fiscal, Available at: http://www.frerealbert.be/fiscalite/fraude-fiscale/les-paradisfiscaux-source-denfer-social-et-fiscal-/ (July, 2018).

8. Stop paradis fiscaux, Available at: http://www.partidegauche66.over-blog.fr/ (July, 2018).

9. Y. Steiner, M. Ruf, Les paradis fiscaux expirent lentement, Available at: http://www.hedbo.ch/44246_html (July, 2018).

10. P.A. Samuelson, W.D. Nordhaus, Ekonomika [Economics] (Binom, Moscow 1997). (in Russian)

11. R.G. Rajan, Linii razloma: skrytye treshhiny, vsjo eshhjo ugrozhajushhie mirovoj ekonomike [Fault Lines: How Hidden Fractures Still Threaten the World Economy] (Gaidar Institute Press, Moscow, 2013). (in Russian)

12. C. Borio, P. Disyatat, Global imbalances and the financial crisis: Link or no link? BIS working papers 346, 43 (Bank for International Settlements Communications, Basel, 2011).

13. J. Ramos-Tallada, Bull. de la Banque de France, 184 (2011).

14. W. Van Lear, J. Sisk, Journal of Economic Issues, Vol. 44 (3), 779-793 (2010).

15. M. Woodford, Journal of Economic Perspectives, Vol. 24 (4), 21-44 (2010).

16. E.S. Rosengren, Defining financial stability, and some policy implications of applying the definition (Boston, 2011).

17. V.A. Bubnov, Thesis of Candidate of economic sciences, Novosibirsk State University of Economics and Management, Novosibirsk, 2017. (in Russian)

18. V.A. Bubnov, Scientific journal Vestnik NSUEM, 2, 312-327 (2017). (in Russian)

19. RZD to Investors, Company Reporting, Available at: http://ir.rzd.ru/static/public/ru?STRUCTURE_ID=32 (May, 2018). (in Russian)

20. RZD to Investors, Borrowing policy and debt obligations, Available at: http://ir.rzd.ru/static/public/ru?STRUCTURE_ID=65 (May 14, 2018). (in Russian) 